\title{
Echocardiographic markers of dyssynchrony as predictors of super- response to cardiac resynchronisation therapy - a pilot study
}

\author{
V. A. Kuznetsov ${ }^{1}$, A. M. Soldatova ${ }^{1 *}$ (D, J. D. Kasprzak² D. V. Krinochkin ${ }^{1}$ and N. N. Melnikov ${ }^{1}$
}

\begin{abstract}
Background: Some patients with congestive heart failure have greater improvement of cardiac remodelling after cardiac resynchronisation therapy (CRT) and they are identified as super-responders (SRs). It remains unclear if echocardiographic markers of dyssynchrony could accuratelly predict super-response to CRT. The aim of this study is to evaluate potential echocardiographic predictors associated with super-response to CRT.

Methods: Fifthy nine CRT patients (mean age $52.9 \pm 9.0$ years, $88 \%$ men) with congestive heart failure (54\% ischaemic and 46\% non-ischaemic aetiology) II-IV NYHA functional class were enrolled. To assess mechanical dyssynchrony we evaluated interventricular mechanical delay, the maximum delay between peak systolic velocities of the septal and posterior walls of left ventricle, duration of left ventricular pre-ejection period (LVPEP), left ventricular and interventricular dyssynchrony by tissue Doppler imaging and systolic dyssynchrony index by 3D echocardiography. After six months the patients were assessed for response and classified as SRs (reduction in left ventricular end-systolic volume (LVESV) $\geq 30 \%, n=20$ ) and non-SRs (reduction in LVESV $<30 \%, n=39$ ) and baseline data were analyzed to identify the predictors.

Results: Both groups demonstrated significant improvement in NYHA functional class, increase in left ventricular ejection fraction and reduction in LVESV. All parameters of mechanical dyssynchrony at baseline were significantly higher in SR group. Multiple logistic regression analysis showed that LVPEP (HR 1.031; 95\% Cl 1.007-1.055; $p=0.011$ ) was an independent predictor for CRT super-response. In ROC curve analysis LVPEP with a cut-off value of $147 \mathrm{~ms}$ demonstrated $73.7 \%$ sensitivity and $75 \%$ specificity (AUC $=0.753 ; p=0.002$ ) for the prediction of super-response to CRT.

Conclusion: Greater mechanical dyssynchrony is associated with super-response to CRT in patients with congestive heart failure. It is probable that an LVPEP > $147 \mathrm{~ms}$ can be used as independent predictor of super-response.
\end{abstract}

Keywords: Dyssynchrony, Cardiac resynchronisation therapy, Super-response

\footnotetext{
* Correspondence: amsoldatova@mail.ru

${ }^{1}$ Tyumen Cardiology Research Center, Tomsk National Research Medical

Center, Russian Academy of Science, Tomsk, Russia, Melnikaite st. 111,

Tyumen 625026, Russia

Full list of author information is available at the end of the article
}

(c) The Author(s). 2018 Open Access This article is distributed under the terms of the Creative Commons Attribution 4.0 International License (http://creativecommons.org/licenses/by/4.0/), which permits unrestricted use, distribution, and reproduction in any medium, provided you give appropriate credit to the original author(s) and the source, provide a link to the Creative Commons license, and indicate if changes were made. The Creative Commons Public Domain Dedication waiver (http://creativecommons.org/publicdomain/zero/1.0/) applies to the data made available in this article, unless otherwise stated. 


\section{Background}

Cardiac resynchronisation therapy (CRT) is an effective treatment for patients with congestive heart failure with reduced ejection fraction (HF-rEF) and prolonged QRS duration. Several large multicentre clinical trials have confirmed that CRT can improve heart function, exercise capacity and quality of life. CRT reduces mortality and hospitalization and can also improve the prognosis in patients with HF-rEF [1]. This benefit is believed to result from the elimination of mechanical asynchrony of the heart.

A decrease in the left ventricular end-systolic volume (LVESV) $\geq 15 \%$ is used as a standardized criterion of CRT response. However, some patients show greater improvement in cardiac function after CRT and are identified as super-responders (SRs) [2].

\section{Aim}

The aim of the study was to evaluate potential echocardiographic predictors associated with super-response to CRT.

\section{Methods}

This study enrolled 59 patients from a local database of implanted CRT devices (mean age $52.9 \pm 9.0$ years, $88 \%$ men) with HF-rEF (32 patients with ischaemic and 27 with non-ischaemic aetiology) [3]. Patients were enrolled where there were available full echocardiographic data at baseline and in terms of dynamics (two-dimensional (2D) and three-dimensional (3D) echocardiography). In 41 patients, we implanted combined devices with a defibrillator function (CRT-D).

The main criteria for CRT implantation were: New York heart association (NYHA) functional class II-IV, reduced left ventricular ejection fraction (LVEF) $<35 \%$, interventricular and/or intraventricular dyssynchrony assessed by echocardiography, with QRS width taken into account $[1,4]$. All patients received medical treatment in accordance with the current guidelines. Device implantation was effective in all patients and occurred without complications.

According to the change in LVESV assessed after six months, the patients were divided into two groups: I) SR (decrease $\geq 30 \%$; $n=20$ ); II) non-SR (decrease $<30 \%, n=39$ ) [5]. Clinical characteristics of the study participants are shown in Table 1.

Standard echocardiography was performed using a commercially available system, i.e., Philips IE 33. Patients underwent baseline and six-month post-implantation echocardiography. The examination included 2D grayscale, colour and spectral blood pool Doppler and tissue Doppler imaging (TDI). Three cardiac cycles were obtained for each acquisition. 3D echocardiograpms were recorded as multibeat electrocardiography-gated data sets, which were obtained over one cardiac cycle. Using 3D echocardiography, we evaluated the left ventricular end-diastolic volume (LVEDV), LVESV, LVEF, stroke volume and systolic dyssynchrony index (SDI) [6, 7]. All Doppler measurements were averaged from three beats.

As for dyssynchrony parameters, three mechanical dyssynchrony indexes were quantified by $2 \mathrm{D}$ echocardiography: septal-to-posterior wall motion delay (SPWMD) (>130 ms), interventricular mechanical delay (IVMD) as the delay in the onset of outflow between the left and right ventricle (with abnormality cut-off $>40 \mathrm{~ms}$ ), and left ventricular preejection period (LVPEP) (abnormality cut-off > $140 \mathrm{~ms}$ ). Interventricular (abnormality cut-off > $120 \mathrm{~ms}$ ) and intraventricular (abnormality cut-off $>60 \mathrm{~ms}$ ) dyssynchrony were assessed by TDI based on the difference between time to onset of the systolic velocity spectrum, recorded from the lateral tricuspid and lateral mitral annulus, using four-chamber apical view (interventricular) and lateral and septal left ventricular annulus, using four-chamber apical view (intraventricular) asynchrony. Additionally, SDI

Table 1 Baseline characteristics of the study groups

\begin{tabular}{lllll}
\hline Parameter & $N=59$ & I group $(n=20)$ & I group $(n=39)$ & $P$ \\
\hline Age, (years) & $52.9 \pm 9.0$ & $52.0 \pm 7.6$ & $53.4 \pm 9.7$ & 0.624 \\
Men, (n) & $88 \%(52 / 59)$ & $85 \%(17 / 20)$ & $90 \%(35 / 39)$ & 0.594 \\
CAD, (\%) & 54 & 47 & $2.8 \pm 0.6$ & 0.308 \\
NYHA functional class & $2.8 \pm 0.6$ & $2.6 \pm 0.6$ & 64 & 0.110 \\
LBBB, (\%) & 59 & 50 & $141.8 \pm 36.7$ & 0.297 \\
QRS, (ms) & $140.9 \pm 38.9$ & $139.1 \pm 44.2$ & 38 & 0.997 \\
Atrial fibrillation, (\%) & 34 & 25 & $231.2 \pm 65.9$ & 0.301 \\
LVEDV, (ml) & $231.9 \pm 65.1$ & $233.4 \pm 65.0$ & $163.5 \pm 51.3$ & 0.288 \\
LVESV, (ml) & $163.5 \pm 49.4$ & $163.4 \pm 46.5$ & $29.6 \pm 3.9$ & 0.475 \\
LVEF, (\%) & $29.8 \pm 3.6$ & $30.0 \pm 2.7$ & 0.458 \\
\hline
\end{tabular}

Tables. 1 and 2: $M \pm S D$ - mean \pm standard deviation, CAD - coronary artery disease, NYHA - New York Heart Association, LBBB- left bundle branch block, LVESV - left ventricular end-systolic volume, LVEDV - left ventricular end-diastolic volume, LVEF - left ventricular ejection fraction 
$\geq 5.6 \%$ assessed by 3D echocardiography, was applied as a criterion of interventricular dyssynchrony [8].

Statistical analyses were performed using SPSS for Windows version 21.0 (SPSS Inc., Chicago, IL, USA). All values had normal distribution, with results expressed as mean value \pm standard deviation (mean $\pm \mathrm{SD}$ ), while mean changes in echocardiographic parameters were expressed as median and the interquartile range (Me [25\%; $75 \%]$ ). Continuous variables were compared using Student's $t$ test. The $x^{2}$ or Fisher's exact test was used to compare categorical variables. Differences in continuous variables between the baseline and follow-up visits were compared using paired $t$-tests. Multiple logistic regression analysis was used to evaluate potential predictors related to super-response. ROC-analysis was used to assess the sensitivity and specificity of evaluated parameters in predicting CRT super-response. $p<0.05$ was considered to be statistically significant.

\section{Results}

At baseline, there were no differences in the demographic, clinical and functional characteristics between the groups (Table 1). After six months, 20 out of 59 (34\%) patients were classified as SRs.

Six months after implantation, both groups demonstrated a significant decrease in NYHA functional class, increase in 6-min walking distance and improvement in echocardiographic parameters according to 3D echocardiography. The improvement in these parameters was significantly higher in SRs, as defined by reverse remodeling (Table 2), including the larger decrease in LVEF.
At baseline, the parameters of mechanical dyssynchrony were significantly more pronounced in SRs: the values of SDI, LVPEP, IVMD, and interventricular delay, as assessed by TDI, were significantly higher in this group (Table 3 ). After six months, the parameters of mechanical dyssynchrony decreased significantly in both groups (Table 3 ). As mean changes of dyssynchrony parameters were more pronounced in SR group in terms of dynamics, the mean values of these parameters did not differ between groups (Table 3).

Multiple logistic regression analysis showed that only LVPEP (HR 1.031; 95\% CI 1.007-1.055; $p=0.011$ ) was an independent predictor for CRT super-response. In ROC curve analysis, LVPEP with a cut-off value of 147 ms demonstrated $73.7 \%$ sensitivity and $75 \%$ specificity (AUC $=0.753 ; p=0.002$ ) for the prediction of super-response to CRT (Fig. 1).

\section{Discussion}

CRT in an effective treatment modality for patients with significant HF-rEF; however, approximately one third of patients do not benefit from this therapy [9]. In contrast, some patients show greater improvement in the cardiac function after CRT implantation and are identified as SRs; this is linked to improved clinical outcomes $[10,11]$, although there is no allowance for the deactivation of CRT as the ventricular dysfunction will return [10]. Our study has identified a simple, Doppler based and thus potentially robust criterion predictive of LV superresponse - LVPEP.

Super-response to CRT was first described in two studies. Blanc et al. found that, in a group of patients with non-ischaemic cardiomyopathy and a left bundle

Table 2 Clinical and functional characteristics at baseline and after 6 months of CRT

\begin{tabular}{|c|c|c|c|c|}
\hline Parameter & & I group $(n=20)$ & $\|$ group $(n=39)$ & $P$ \\
\hline \multirow[t]{2}{*}{ NYHA functional class } & At baseline & $2.6 \pm 0.6$ & $2.8 \pm 0.6$ & 0.107 \\
\hline & After 6 months & $1.9 \pm 0.7^{\mathrm{a}}$ & $2.2 \pm 0.9^{\mathrm{a}}$ & 0.169 \\
\hline \multirow[t]{2}{*}{ 6-min walking distance, $(\mathrm{m})$} & At baseline & $329.2 \pm 86.0$ & $320.9 \pm 98.7$ & 0.651 \\
\hline & After 6 months & $421.5 \pm 66.7^{\mathrm{a}}$ & $381.5 \pm 112.2^{\mathrm{a}}$ & 0.169 \\
\hline \multirow[t]{3}{*}{ LVEF by 3D echocardiography, (\%) } & At baseline & $30.0 \pm 2.7$ & $29.6 \pm 3.9$ & 0.458 \\
\hline & After 6 months & $40.1 \pm 5.4^{\mathrm{a}}$ & $34.4 \pm 3.8^{\mathrm{a}}$ & $<0.001$ \\
\hline & Mean changes & $10[6.2 ; 13.2]$ & $5[3 ; 7]$ & $<0.001$ \\
\hline \multirow[t]{3}{*}{ LVEDV by 3D echocardiography, (ml) } & At baseline & $233.4 \pm 65.0$ & $231.2 \pm 65.9$ & 0.820 \\
\hline & After 6 months & $159.1 \pm 39.4^{\mathrm{a}}$ & $213.2 \pm 63.7^{\mathrm{a}}$ & $<0.001$ \\
\hline & Mean changes & $-73.0[-101.0 ;-51.7]$ & $-15.0[-31.0 ;-8.0]$ & $<0.001$ \\
\hline \multirow[t]{3}{*}{ LVESV by 3D echocardiography, (ml) } & At baseline & $163.4 \pm 46.5$ & $163.5 \pm 51.3$ & 0.957 \\
\hline & After 6 months & $95.8 \pm 27.1^{\mathrm{a}}$ & $140.0 \pm 46.7^{\mathrm{a}}$ & $<0.001$ \\
\hline & Mean changes & $-61.0[-91.0 ;-47.7]$ & $-20.0[-38.0 ;-12.0]$ & $<0.001$ \\
\hline \multirow[t]{2}{*}{ QRS, (ms) } & At baseline & $139.1 \pm 44.2$ & $141.8 \pm 36.7$ & 0.996 \\
\hline & After 6 months & $153.6 \pm 26.2$ & $160.2 \pm 26.0^{\mathrm{a}}$ & 0.367 \\
\hline
\end{tabular}

a - difference between baseline and postimplant value $(p<0.05)$ 
Table 3 Parameters of mechanical dyssynchrony at baseline and after 6 months of CRT

\begin{tabular}{|c|c|c|c|c|}
\hline Parameter & & I group $(n=20)$ & II group $(n=39)$ & $P$ \\
\hline \multirow[t]{3}{*}{ Systolic dyssynchrony index, (\%) } & At baseline & $9.5 \pm 3.4$ & $7.5 \pm 4.4$ & 0.05 \\
\hline & After 6 months & $2.8 \pm 1.2^{\mathrm{a}}$ & $3.1 \pm 1.2^{\mathrm{a}}$ & 0.278 \\
\hline & Mean changes & $-6.4[-8.7 ;-4.3]$ & $-2.8[-8.2 ;-0.36]$ & 0.044 \\
\hline \multirow[t]{3}{*}{ Left ventricular pre-ejection period, (ms) } & At baseline & $160.5 \pm 31.2$ & $131.5 \pm 29.5$ & 0.002 \\
\hline & After 6 months & $127.7 \pm 22.8^{\mathrm{a}}$ & $118.3 \pm 21.2^{\mathrm{a}}$ & 0.292 \\
\hline & Mean changes & $-35.5[-53.7 ;-11.2]$ & $-18.5[-35.0 ; 1.7]$ & 0.043 \\
\hline \multirow[t]{3}{*}{ Right ventricular pre-ejection period, (ms) } & At baseline & $102.1 \pm 21.4$ & $95.4 \pm 18.6$ & 0.249 \\
\hline & After 6 months & $106.4 \pm 16.7$ & $103.3 \pm 26.2$ & 0.716 \\
\hline & Mean changes & $9.5[-17.0 ; 30.7]$ & $14.5[-13.5 ; 33.5]$ & 0.512 \\
\hline \multirow[t]{3}{*}{ Interventricular mechanical delay, (ms) } & At baseline & $57.5 \pm 28.3$ & $39.7 \pm 24.2$ & 0.024 \\
\hline & After 6 months & $19.9 \pm 15.9^{a}$ & $25.4 \pm 11.7$ & 0.357 \\
\hline & Mean changes & $-47.0[-55.0 ;-13.0]$ & $-11.0[-36.5 ; 3.0]$ & 0.054 \\
\hline \multirow[t]{3}{*}{ Interventricular delay by TDI, (ms) } & At baseline & $110.2 \pm 66.1$ & $71.6 \pm 57.9$ & 0.038 \\
\hline & After 6 months & $58.4 \pm 56.7^{\mathrm{a}}$ & $50.6 \pm 48.3^{a}$ & 0.653 \\
\hline & Mean changes & $-31.0[-120 ; 12.5]$ & $-20.5[-66.2 ; 8.2]$ & 0.165 \\
\hline \multirow[t]{3}{*}{ Intraventricular delay by TDI, (ms) } & At baseline & $88.4 \pm 45.3$ & $67.7 \pm 42.8$ & 0.098 \\
\hline & After 6 months & $54.7 \pm 44.9^{a}$ & $36.9 \pm 25.5$ & 0.568 \\
\hline & Mean changes & $-57.5[-80.2 ;-28.0]$ & $-12.0[-40.0 ; 15.0]$ & 0.005 \\
\hline
\end{tabular}

$T D I$ - tissue Doppler imaging

a - difference between baseline and postimplant level $(p<0.05)$

branch block (LBBB), some exhibited a normalization of LVEF $>50 \%$ after CRT [12]. Bulava et al., meanwhile, described a case study of a patient suffering from severe HF-rEF. The case represented exceptional left ventricular reverse remodelling with practically normalized left ventricular function after one year of synchronized pacing [13]. In recent studies, the dynamics of LVEF were used as a criterion of super-response; however, their level differed from study to study $[14,15]$.
To date, there is no universally accepted criterion of super-response. Some authors defined SRs in terms of an improvement in LVESV although different cut-offs were selected $[16,17]$. In our study, a super-response was defined as a relative reduction in LVESV $>30 \%$ after six months of CRT according to several studies [2, 11, 12]. Steffel et al. previously compared three definitions for a super-response: defined by an absolute increase in LVEF of $10 \%$, a decrease in the LVESV index by $30 \%$

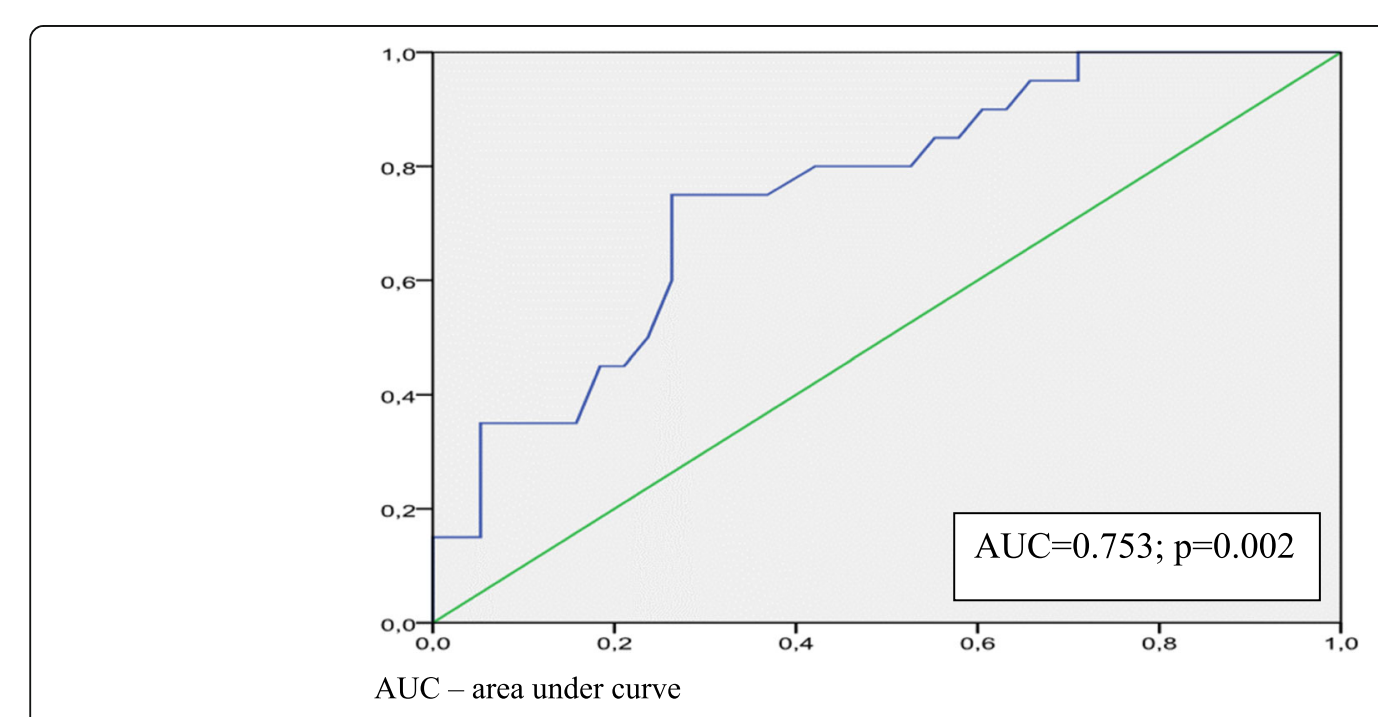

Fig. 1 ROC-curve for sensitivity and specificity of LVPEP in prediction of response to CRT. AUC - area under curve 
and a decrease in the LVEDV index by $20 \%$. The authors found that any of these cut-off points is highly predictive of clinical improvement and survival after CRT implantation [16]. A large study by Ypenburg linked the definition, which was accepted for this study (reduction in LVESV $\geq 30 \%$ ), with improved clinical outcomes [5].

Prior clinical studies have reported the incidence of super-response to be in the range of 10-29\% [18]. In the majority of studies, super-response was defined as LVEF $>50 \%$ together with a functional recovery NYHA class of I or II $[19,20]$. In other studies, a super-response was defined as decrease in LVESV $\geq 30 \%[5,21]$. At the six-month follow-up, stage $22 \%$ of patients were defined as SRs (32\% without LBBB). SR presented more extensive mechanical dyssynchrony at baseline [5]. In the case of PROSPECT sub-analysis, the percentage of SRs at six-months follow-up was $37.8 \%$, they also presented more evidence of mechanical dyssynchrony [21]. In our study, we observed a high percentage of SRs (34\%), although this corresponded to other studies in which the same SR criteria were used. The lack of a universal definition of super-response to CRT is presumably one of the main reasons for such a wide discrepancies between studies. The positive results from our study could be explained by good patient selection, along with the decision to assess mechanical dyssynchrony parameters using 2D and 3D echocardiography. The utilization of mechanical dyssynchrony parameters for patient selection to CRT may also explain the significant positive effect of CRT in the CARE-HF trial [4].

Different factors associated with super-response to CRT have been reported. Jin reported that biventricular pacing percentage greater than $98 \%$ was a good predictor of a super-response [22]. Some data suggest that patients with non-ischemic cardiomyopathy and an absence of myocardial infarction receive the greatest benefit from CRT, while patients with ischaemic heart disease tend to respond to CRT to a less extent than patients with non-ischaemic cardiomyopathy [14, 16, 23]. According to PROSPECT sub-analysis, patients with ischaemic HF showed less improvement in LVESV after CRT, although it is noteworthy that $31.8 \%$ of them were classified as SRs [21]. In our study, $54 \%$ of patients $(n=32)$ had ischaemic aetiology of HF, while $71.9 \%$ of them $(n=23)$ were SRs. In univariate and multivariate analysis non-ischaemic aetiology of $\mathrm{HF}$ was not associated with super-response to CRT.

In our study, SRs demonstrated more pronounced improvement in echocardiographic parameters and an increase in LVEF. At the same time, it is obvious that the group of non-SRs $(n=39)$ was not homogeneous: $41 \%$ of patients $(n=16)$ were non-responders (a decrease in LVESV < $15 \%)$ and $59 \%$ of patients $(n=23)$ were responders (a decrease in LVESV 15-29\%). Furthermore, the effect of CRT could be quite different between these subgroups, but this issue needs further investigation.

Despite different response criteria, in most studies with LBBB derived greater benefits from CRT [1]. Large multicentre studies have demonstrated that LBBB is associated with CRT response and long-term survival. At the same time, patients with non-LBBB morphology of QRS are less representative in clinical trials (less than $15 \%)$; therefore, little can be definitively inferred regarding the efficacy of CRT among these patients. There is also a lack of standardization in terms of QRS width and morphology in clinical trials and large studies [24]. Thus, in real clinical practice, the significance of QRS morphology for patient selection to CRT is still not clear. The presence of left hemiblock in right bundle branch block patients improved outcomes and, according to Rocha et al., these patients also became SRs (46\% of the total SRs) $[23,25]$. The success of CRT in patients with non-LBBB morphology of QRS can be associated with the presence of mechanical dyssynchrony [26, 27]. In our study LBBB was observed in $50 \%$ of SRs and $64 \%$ of non-SRs. Both groups demonstrated significant improvement in NYHA functional class, a decrease in LVESV and LVEDV and an increase in LVEF. However, improvement in these parameters was significantly higher in SRs. LBBB was not found to be a predictive factor of a greater response to CRT.

There is a link between electrical and mechanical dyssynchrony, but it is not always clearly identified. Some patients with normal QRS demonstrate significant mechanical disorders, however the question about the utilization of mechanical dyssynchrony parameters to predict CRT response is still unanswered [6, 7]. Some authors have described TDI and speckle tracking echocardiography parameters as predictors of CRT response [28-30]. In our study, the groups did not differ in terms of QRS width, while the mean level of QRS in SRs and non-SRs was relatively low $(139.1 \pm 44.2 \mathrm{~ms}$ and 141.8 $\pm 36.7 \mathrm{~ms}$, respectively) but the parameters of mechanical dyssynchrony significantly differed between groups, with greater mechanical dyssynchrony in patients with super-response to CRT. Among the SRs, all parameters of inter- and intraventricular dyssynchrony decreased after six months of CRT; among the non-SRs, the parameters of intraventricular dyssynchrony also reduced significantly. However, the width of the QRS complex increased in both groups. This may be explained by the widening of the QRS complex in patients with narrow baseline QRS $(<120 \mathrm{~ms})$, given that CRT conduction differs from normal conduction, such that we can create artificial electrical dyssynchrony in these patients. At the same time, a significant clinical effect and reverse remodelling in SRs support the idea of a positive effect of CRT on the elimination of mechanical 
dyssynchrony, which is more significant than in the appearance of electrical disorders.

\section{Limitations}

Our study has several limitations. This pilot study only involved a single centre and a retrospective protocol. The patient count was also limited; however, we were able to identify a number of SRs that was sufficient for statistical comparison purposes.

The study enrolled patients from a local database of implanted CRT devices; thus, the heterogeneity of patients included in this study was the result of real clinical practice. $54 \%$ of patients enrolled on our study had ischaemic aetiology of HF, which, in percentage terms, corresponds to a study cohort in large multicentre studies [31, 32].

The mean QRS width in our patients was $140.9 \pm$ $38.9 \mathrm{~ms}$, while $59 \%$ of patients had LBBB. Enrolment began in January 2009 and ended in December 2015. Until 2012 (about half of the enrolment period), a QRS width > $120 \mathrm{~ms}$ was one of the main criteria for CRT implantation. We enrolled patients with a QRS width > $120 \mathrm{~ms}$ or $<120 \mathrm{~ms}$ + two parameters of mechanical dyssynchrony. It should be noted that, from 2005 until the latest update to the clinical recommendations in 2013, in our clinic, we used the St. Mary's Hospital and Imperial College (London) protocol for CRT implantation, which included parameters of mechanical dyssynchrony assessed by TDI [33].

New echocardiographic techniques, such as speckle tracking, visual criteria of dyssynchrony as apical rocking, septal flash and visual late lateral activation, were not evaluated.

Due to our retrospective design, no intra- or interobserver reproducibility analysis of this study was performed regarding electrocardiographic and echocardiographic variables.

\section{Conclusion}

Greater mechanical dyssynchrony is associated with super-response to CRT. It is probable that an LVPEP $>147 \mathrm{~ms}$ can be used as an independent predictor of super-response.

\footnotetext{
Abbreviations

2D: 2-dimensional; 3D: 3-dimensional; CRT: Cardiac resynchronisation therapy; CRT-D: Cardiac resynchronisation therapy with defibrillator function; HFrEF: Heart failure with reduced ejection fraction; IVMD: Interventricular mechanical delay; LBBB: Left bundle branch block; LVEDV: Left ventricular end-diastolic volume; LVEF: Left ventricular ejection fraction; LVESV: Left ventricular end-systolic volume; LVPEP: Left ventricular preejection period; NYHA: New York heart association; SDI: Systolic dyssynchrony index; SPWMD: Septal-to-posterior wall motion delay; SR: Super-responder; TDI: Tissue Doppler imaging
}

Funding

Tyumen Cardiology Research Center, Tomsk National Research Medical Center, Russian Academy of Science, Tomsk, Russia.

\section{Availability of data and materials}

Kuznetsov V.A., Kolunin G.V., Kharats V.E., Krinochkin D.V., Rychkov A.Yu., Gorbunova T.Y., Pavlov A.V., Belonogov D.V., Churkevich T.O. Register of performed operations of cardiac resynchronization therapy. Electronic database, state registration №2,010,620,077 from 01.02.2010 (In Rus.).

\section{Authors' contributions}

Concept KVA, SAM; Design KVA, KJD, SAM; Supervision KVA, KDV; Providing tools and instruments KDV, SAM, MNN; Data collection and/or processing

SAM, KDV, MNN; Analysis and/or interpretation SAM, MNN; Literature review SAM MNN KJD; Writing SAM, MNN; Critical review KVA, KJD. All authors read and approved the final manuscript.

\section{Ethics approval and consent to participate}

The study was conducted in accordance with the ethical standards of the Local Institutional Review Board and with the 1964 Helsinki declaration and its later amendments. This project was approved by the Local Bioethics Committee. All patients gave their written informed consent before the study.

\section{Consent for publication}

Not applicable.

\section{Competing interests}

The authors declare that they have no competing interests.

\section{Publisher's Note}

Springer Nature remains neutral with regard to jurisdictional claims in published maps and institutional affiliations.

\section{Author details}

${ }^{1}$ Tyumen Cardiology Research Center, Tomsk National Research Medical Center, Russian Academy of Science, Tomsk, Russia, Melnikaite st. 111, Tyumen 625026, Russia. ${ }^{2}$ Department of Cardiology, Medical University of Lodz, Bieganski Hospital, Kniaziewicza 1/5, 91-347, Lodz, Poland.

Received: 18 May 2018 Accepted: 21 August 2018

Published online: 02 October 2018

\section{References}

1. Priori SG, Blomström-Lundqvist C, Mazzanti A, Blom N, Borggrefe M, Camm J, Elliott PM, Fitzsimons D, Hatala R, Hindricks G, Kirchhof P, Kjeldsen K, Kuck KH, Hernandez-Madrid A, Nikolaou N, Norekvål TM, Spaulding C, Van Veldhuisen DJ, et al. 2015 ESC guidelines for the management of patients with ventricular arrhythmias and the prevention of sudden cardiac death the task force for the Management of Patients with ventricular arrhythmias and the prevention of sudden cardiac death of the European Society of Cardiology (ESC) endorsed by: Association for European Paediatric and Congenital Cardiology (AEPC). Europace. 2015;17(11):1601-87. https://doi. org/10.1093/eurheartj/ehv316.

2. Van 't Sant J, Mast TP, Bos MM, Ter Horst IA, van Everdingen WM, Meine M, Cramer MJ. Echo response and clinical outcome in CRT patients. Neth Heart J. 2016;24(1):47-55. https://doi.org/10.1007/s12471-015-0767-5.

3. Kuznetsov V.A., Kolunin G.V., Kharats V.E., Krinochkin D.V., Rychkov A.Yu., Gorbunova T.Y., Pavlov A.V., Belonogov D.V., Churkevich T.O. Register of performed operations of cardiac resynchronization therapy. Electronic database, state registration №2010620077 from 01.02.2010 (In Rus.)

4. Cleland JGF, Daubert JC, Erdmann E, Freemantle N, Gras D, Kappenberger L, Tavazzi $L$. The effect of cardiac resynchronization on morbidity and mortality in heart failure. (CARE-HF) N Engl J Med. 2005;352:1539-49. https://doi.org/10.1056/NEJMoa050496.

5. Ypenburg C, van Bommel RJ, Borleffs CJ, Bleeker GB, Boersma E, Schalij MJ, Bax JJ. Long-term prognosis after cardiac resynchronization therapy is related to the extent of left ventricular reverse remodeling at midterm follow-up. J Am Coll Cardiol. 2009;53:483-90. https://doi.org/10.1016/j.jacc. 2008.10.032 
6. Van Everdingen WM, Schipper JC, van 't Sant J, Ramdat Misier K, Meine M, Cramer MJ. Echocardiography and cardiac resynchronisation therapy, friends or foes? Neth Heart J. 2016;24(1):25-38. https://doi.org/10.1007/s12471-015-0769-3.

7. El Missiri AM. Echocardiographic assessment of left ventricular mechanical dyssynchrony - a practical approach. The Egypt Heart J. 2014;66(3):217-25.

8. Kuznetsov VA, Krinochkin DV, Melnikov NN, Kolunin GV, Kharats VE, Gorbatenko EA. 3D-echocardiography for predicting response to cardiac resynchronization therapy in patients with congestive heart failure. Medicinskaya Visualizacia. 2012;3:93-9.

9. Dhesi S, Lockwood E, Sandhu RK. Troubleshooting cardiac resynchronization therapy in non-responders. Can J Cardiol. 2017; https://doi.org/10.1016/j. cjca.2017.04.007.

10. Cay S, Ozeke O, Ozcan F, Aras D, Topaloglu S. Mid-term clinical and echocardiographic evaluation of super responders with and without pacing: the preliminary results of a prospective, randomized, singleCentre study. Europace. 2016;18(6):842-50. https://doi.org/10.1093/ europace/euv129. Epub 2015 May 27

11. Van der Heijden AC, Höke U, Thijssen J, Willem Borleffs CJ, Wolterbeek R, Schalij MJ, van Erven L. Long-term echocardiographic outcome in superresponders to cardiac resynchronization therapy and the association with mortality and defibrillator therapy. Am J Cardiol. 2016;118(8):1217-24. https://doi.org/10.1016/j.amjcard.2016.07.041. Epub 2016 Jul 29

12. Blank JJ, Fatemi M, Bertault V, Baraket F, Etienne Y. Evaluation of left bundle branch block as a reversible cause of non-ischaemic dilated cardiomyopathy with severe heart failure. A New Concept of Left Ventricular Dyssynchrony-Induced Cardiomyopathy Europace. 2005;7:60410. https://doi.org/10.1016/j.eupc.2005.06.005.

13. Bulava A, Lukl J, Skvarilová M, Marek D. Dramatically improved left ventricular function after biventricular pacemaker implantation-a case report. Eur J Heart Fail. 2005;7:231-3. https://doi.org/10.1016/j.ejheart. 2004.09.017.

14. Killu AM, Grupper A, Friedman PA, Powell BD, Asirvatham SJ, Espinosa RE, Luria D, Rozen G, Buber J, Lee YH, Webster T, Brooke KL, Hodge DO, Wiste HJ, Glikson M, Cha YM. Predictors and Outcomes of "Superresponse" to Cardiac Resynchronization Therapy. J Card Fail. 2014;20(6) 379-86. https://doi.org/10.1016/j.cardfail.2014.03.001. Epub 2014 Mar 12

15. Zecchin M, Proclemer A, Magnani S, Vitali-Serdoz L, Facchin D, Muser D. Long-term outcome of 'super-responder' patients to cardiac resynchronization therapy. Europace. 2014;16(3):363-71. https://doi.org/10 1093/europace/eut339.

16. Steffel J, Ruschitzka F. Superresponse to cardiac resynchronization therapy. Circulation. 2014;130(1):87-90. https://doi.org/10.1161/CIRCULATIONAHA. 113.006124

17. Yanagisawa S, Inden Y, Shimano M, Yoshida N, Fujita M, Ohguchi S, Ishikawa S, Kato H, Okumura S, Miyoshi A, Nagao T, Yamamoto T, Hirai M, Murohara T. Clinical characteristics and predictors of super-response to cardiac resynchronization therapy: a combination of predictive factors. Pacing Clin Electrophysiol. 2014; 37(11):1553-64. https:/doi.org/10.1111/pace.12506. Epub 2014 Sep 16

18. Ellenbogen KA, Huizar JF. Foreseeing super-response to cardiac resynchronization therapy: a perspective for clinicians. J Am Coll Cardiol. 2012 Jun 19;59(25):2374-7. https://doi.org/10.1016/j.jacc.2011.11.074

19. Reant P, Zaroui A, Donal E, Mignot A, Bordachar P, Deplagne A, Solnon A, Ritter P, Daubert JC, Clementy J, Leclerca C, Roudaut R, Habib G, Lafitte S. Identification and characterization of super-responders after cardiac resynchronization therapy. Am J Cardiol. 2010;105:1327-35. https://doi.org/ 10.1016/j.amjcard.2009.12.058

20. Serdoz LV, Daleffe E, Merlo M, Zecchin M, Barbati G, Pecora D, Pinamonti B, Fantoni C, Lupo P, Di Lenarda A, Sinagra G, Cappato R. Predictors for restoration of normal left ventricular function in response to cardiac resynchronization therapy measured at time of implantation. Am J Cardiol. 2011;108:75-80. https://doi.org/10.1016/j.amjcard.2011.02.347.

21. van Bommel RJ, Bax JJ, Abraham WT, Chung ES, Pires LA, Tavazzi L, Zimetbaum PJ, Gerritse B, Kristiansen N, Ghio S. Characteristics of heart failure patients associated with good and poor response to cardiac resynchronization therapy: a PROSPECT (Predictors of Response to CRT) sub-analysis. Eur Heart J. 2009;30: 2470-7. https://doi.org/10.1093/eurheart//ehp368.

22. Jin H, Gu M, Hua W, Fan XH, Niu HX, Ding LG, Wang J, Xue C, Zhang S. Predictors of super-response to cardiac resynchronization therapy: the significance of heart failure medication, pre-implant left ventricular geometry and high percentage of biventricular pacing. J Geriatr Cardiol. 2017;14(12):737-42. https://doi.org/10.11909/j.issn.1671-5411.2017.12.003.
23. Rocha EA, Pereira FTM, Quidute ARP, Abreu JS, Lima JWO, Rodrigues Sobrinho CRM, Scanavacca MI. Who are the super-responders to cardiac resynchronization therapy? Intl J Cardiovasc Sci. 2017;30(1):61-9. https://doi. org/10.5935/2359-4802.20170020

24. Turagam MK, Velagapudi P, Kocheril AG. Standardization of QRS duration measurement and LBBB criteria in CRT trials and clinical practice. Curr Cardiol Rev. 2013;9:20-3. https://doi.org/10.2174/157340313805076269.

25. Chandra R, Zolty R, Palma E. A left hemiblock improves cardiac resynchronization therapy outcomes in patients with a right bundle branch block. Clin Cardiol. 2010;33:89-93.

26. Hara H, Oyenuga OA, Tanaka H, Adelstein EC, Onishi T, McNamara DM, Schwartzman D, Saba S, Gorcsan J 3rd. The relationship of QRS morphology and mechanical dyssynchrony to long-term outcome following cardiac resynchronization therapy. Eur Heart J. 2012;33(21):2680-91. https://doi.org/ 10.1093/eurheartj/ehs013.

27. Leong DP, Höke U, Delgado V, Auger D, Thijssen J, van Erven L, Bax JJ, Schalij MJ, Marsan NA. Predictors of long-term benefit of cardiac resynchronization therapy in patients with right bundle branch block. Eur Heart J. 2012 Aug;33(15):1934-41. https://doi.org/10.1093/eurheartj/ehr470.

28. Mele D, Bertini M, Malagù M, Nardozza M, Ferrari R. Current role of echocardiography in cardiac resynchronization therapy. Heart Failure Rev. 2017;22(6):699-722. https://doi.org/10.1007/s10741-017-9636-1.

29. Maréchaux S, Guiot A, Castel A, Guyomar Y, Semichon M, Delelis F, Heuls S, Ennezat PV, Graux P. Tribouilloy C. Relationship between two-dimensional speckle-tracking Septal strain and response to cardiac resynchronization therapy in patients with left ventricular dysfunction and left bundle branch block: a prospective pilot study. J Am Soc Echocardiogr. 2014;27(5):501-11. https://doi.org/10.1016/..echo.2014.01.004. Epub 2014 Feb 8

30. Szymczyk E, Lipiec P, Michalski B, Kasprzak JD. 2D and 3D speckle tracking echocardiography: clinical application. Kardiol Pol. 2013;71(1):77-83.

31. Kang SH, Oh IY, Kang DY, Cha MJ, Cho Y, Choi EK, Hahn S, Oh S. Cardiac resynchronization therapy and QRS duration: systematic review, metaanalysis, and meta-regression. J Korean Med Sci. 2015 Jan;30(1):24-33. https://doi.org/10.3346/jkms.2015.30.1.24.

32. Yokoshiki H, Mitsuyama H, Watanabe M, Mitsuhashi T, Shimizu A. Cardiac resynchronization therapy in ischemic and non-ischemic cardiomyopathy. J Arrhythm. 2017;33(5):410-6. https://doi.org/10.1016/j.joa.2017.03.002.

33. Whinnett ZI, Davies JE, Lane RE, Francis DP, Mayet J. Echocardiographic methods for selecting patients suitable for biventricular pacing therapy. Minerva Cardioangiol. 2005;53(3):211-20.
Ready to submit your research? Choose BMC and benefit from:
- fast, convenient online submission
- thorough peer review by experienced researchers in your field
- rapid publication on acceptance
- support for research data, including large and complex data types
- gold Open Access which fosters wider collaboration and increased citations
- maximum visibility for your research: over $100 \mathrm{M}$ website views per year
At BMC, research is always in progress. 